\title{
Contractile Force and Stitch Modeling of Shape Memory Alloy Knitted Fabric Actuators
}

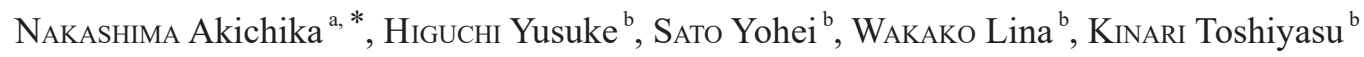 \\ ${ }^{a}$ Industrial Research Institute of Ishikawa, 2-1 Kuratsuki, Kanazawa, Ishikawa 920-8203, Japan \\ ${ }^{\mathrm{b}}$ Kanazawa University, Kakumamachi, Kanazawa, Ishikawa 920-1192, Japan
}

Received 1 July 2020; accepted for publication 12 January 2021

\begin{abstract}
To improve the calculation accuracy of the contractile force in a shape memory alloy (SMA) knitted fabric actuator, which was developed in a previous study, we measured the Young's modulus, $E$, and wire diameter, $d$, of a SMA yarn in unheated $\left(20^{\circ} \mathrm{C}\right)$ and heated $\left(100^{\circ} \mathrm{C}\right)$ environments. Subsequently, the contractile force in the heated environment was calculated in terms of bending rigidity ( $E I)$ using the measured values of $E$ and $d$. The accuracy of the theoretical contractile force, considering contraction and increment in $E I$, was improved when compared with that in the former one, which only considered contraction of the SMA yarn. Furthermore, to enhance calculation accuracy, we proposed a 2 dimensional stitch model for SMA plain knitted fabric. This model consisted of clothoid curves through four contact points, where each yarn crosses the other stitches and act forces. Further, this model could show the change in the curvature via the contraction of the yarn as well as the increase in its potential energy. Therefore, it was confirmed that this model is useful for calculating the contractile force of the SMA knitted fabric.
\end{abstract}

Key Words : Smart textile, Knit, Soft actuator, Shape memory alloy (SMA), Modeling

\section{形状記憶合金平編地アクチュエータの収縮力と 編目モデリング}

中島明哉 ${ }^{\mathrm{a}, *}$, 樋口雄亮 ${ }^{\mathrm{b}}$, 佐藤洋平 ${ }^{\mathrm{b}}$, 若子倫菜 ${ }^{\mathrm{b}}$, 喜成年泰 ${ }^{\mathrm{b}}$

${ }^{a}$ 石川県工業試験場, ${ }^{b}$ 金沢大学

\section{1. 緒 言}

近年, 疾病予防や健康増進など健康寿命を延伸するツール の一つとして, 衣類に用いられるテキスタイル技術と電子デ バイスを融合するスマートテキスタイルと呼ばれる分野が注 目を集めている。この分野では，これまでにセンサ機能を持 つスマートテキスタイルとして, 圧力検知が可能なテキス タイルセンサ [1-5] や人体動作の計測のためのウェアラブル センサが開発 [6,7] され, 疾病予防のための体調管理を目的 とした機能素材や衣服の研究開発 [8-14] が進められてきた. これらテキスタイルセンサによるバイタルデータ収集は経時 的変化を把握することができる点で特に有効である。そのう
えで，この収集したデータをもとにテキスタイルから人体へ 何らかのアクションが可能となれば, 更なる健康寿命の延伸 が期待できる。しかしながら，そのようなアクションを生み 出すスマートテキスタイルについての実用的な研究報告は多 くなく, アクチュエータ機能については出力が小さいことや 低い応答性など, 解決しなければならない点が多い [15-23]. そこで, 我々は衣類など既存の繊維製品に組み込むことを目 的としたテキスタイルアクチュエータとして, 温度変化によ り長さ方向に伸縮変形する特徵を持つ形状記憶合金ワイヤー （以下, SMA 糸とする.) からなる, 形状記憶処理の必要が ない編地アクチュエータを開発 [24]した。

この編地アクチュエータの構成要素である形状記憶合金平

* 連絡先：石川県工業試験場９20-8203 金沢市鞍月 2-1

E-mail : nakasima@irii.jp, Tel : +81-76-267-8083,Fax : +81-76-267-8090 
編地（以下, SMA 平編地とする.) について, ウェール方向 の定速引張荷重試験にて定量的に評価し, 清水ら [25] が提 案しているウェール方向引つ張り特性の理論結果と比較する ことで，この理論式が適用可能なことを示した $[26]$. そのう えで, SMA 編地の収縮力発生機構を解明することを目的に, 純曲げ試験機を用いて SMA 糸の曲げ剛性を測定した。その 結果, 恒温恒湿室内 $\left(20 \pm 2{ }^{\circ} \mathrm{C}, 65 \pm 4 \%\right.$ R.H. $)$ では $2.7 \times 10^{-7}$ $\mathrm{Nm}^{2}$ であった曲げ剛性が, $100{ }^{\circ} \mathrm{C}$ に通電加熱すると $5.7 \times 10^{-7}$ $\mathrm{Nm}^{2}$ に増加していることを確認し, 収縮力の発生には SMA 糸の収縮だけでなく曲げ剛性の増大が影響していることを報 告した [26]。しかしながら，この純曲げ試験機による剛性 の測定では，加熱時に剛性が高くなることによる影響が大き く, 正確な曲げ剛性值を算出できなかった。 そこで本報では, SMA 平編地の収縮力算出精度の向上を図ることを目的に, SMA 糸の曲げ剛性值を正確に求める方法として，加熱によ るヤング率の変化量と SMA 糸の直径変化量を測定し, 理論 収縮力をより正確に計算することに取り組んだのでここに報 告する。ささらに, 収縮力算出精度の向上を目指し, ロボット の軌道生成 [27-29] 等に使用されてきたクロソイド曲線を新 たに編目のモデリングの補間曲線として用いることを提案す る.

\section{SMA 平編地の収縮力について}

前報 [26]において, 清水ら [25] がFig. 1 のモ゙ルから 導出したウェール方向引つ張り特性の理論と SMA 平編地の ウェール方向の引っ張り特性について, SMA 平編地の引張試 験にて定量的に評価した。 その結果, Fig. 2 に示すとおり糸 は伸びない $\left(P / k_{u}=0\right)$ と仮定して計算した理論值と実験值がほ ぼ一致することを確認し, 以下の式 (1), (2) が SMA 平編地 にも適用可能なことを示した。

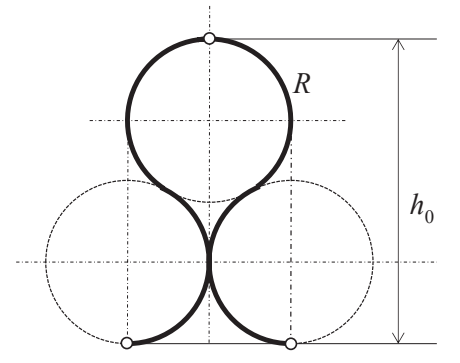

(a)

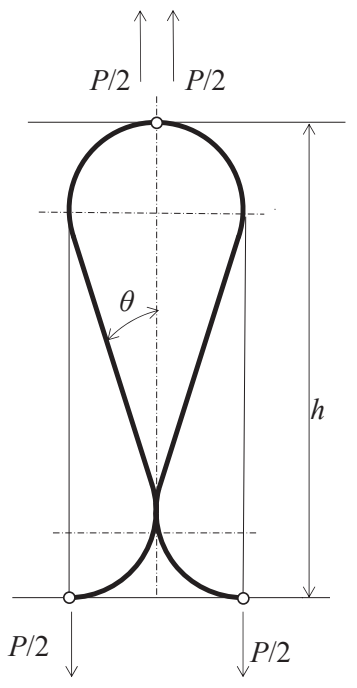

(b)
Fig. 1 Models relative to apexes of stitch[25]. (a)Initial shape (b)Stretched shape

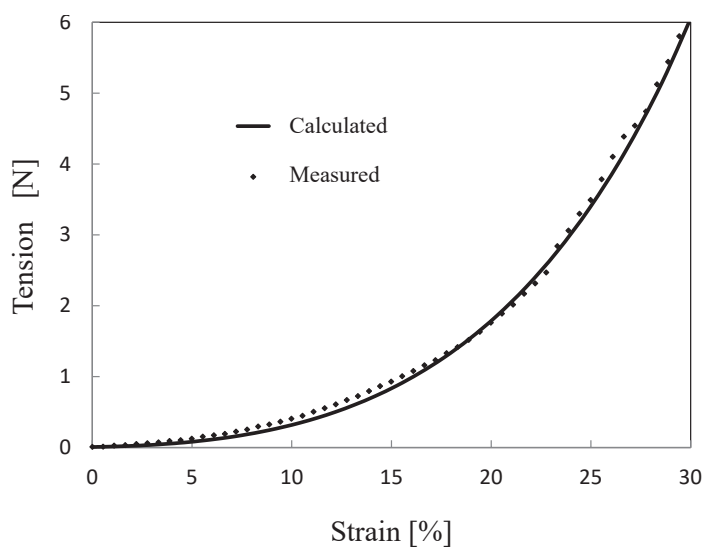

Fig. 2 Calculated and measured tension of SMA plain knitted fabric at $20^{\circ} \mathrm{C}$.

$$
\begin{aligned}
& P=\frac{2 E I F_{0}(\theta)}{h_{0}{ }^{2}} \\
& \varepsilon=\frac{10.472\{n g(\theta)-n+1\}}{h_{0}{ }^{2}}-1
\end{aligned}
$$

ただし $n$ ははループの個数, $P$ は荷重, $\varepsilon$ は伸び,

$$
\begin{aligned}
& F_{0}(\theta)=\frac{2 \times 3.732^{2}}{10.472^{2}}\left[f(\theta)-f\left(\theta=60^{\circ}\right)-\frac{P}{k_{u}} g(\theta)\right]^{2} \\
& g(\theta)=\frac{2+2 \sin \theta-\cos \theta}{\sin \theta} \\
& f(\theta)=2 \pi+4 \theta+\frac{2 \cos \theta-1}{\sin \theta}
\end{aligned}
$$

であり, $E I$ はループを構成する糸の曲げ剛性, $h_{0}$ はループの 初期高さ， $k_{u}$ は糸のばね定数を単位長さ引っ張ったときの值 に換算したものである.

\subsection{SMA 糸のヤング率}

SMA 糸の加熱による曲げ剛性の増加に影響を与えるパラ メータとして，ヤング率の変化が考えられる. SMA糸は熱 により相変位が起きているため, ヤング率が変化している可 能性が高い。そこで恒温槽付き万能試験機（AG-100kNplus, 島津製作所株式会社製）を用いて, 恒温槽内で SMA 系一本 の引張試験を行なった. 引張速度は $1 \mathrm{~mm} / \mathrm{min}$, 恒温槽内の温 度は非加熱時 $20{ }^{\circ} \mathrm{C}$, 加熱時 $100{ }^{\circ} \mathrm{C}$ とたた。 各条件における 測定結果はFig. 3 のようになり，2つの応力 - ひずみ特性曲 線は明らかに異なっていることから, SMA 糸の応力 - ひずみ 特性は加熱により変化していることが分かった。この結果か ら, SMA 糸の動作が保証されている許容引張限界值 $83 \mathrm{MPa}$

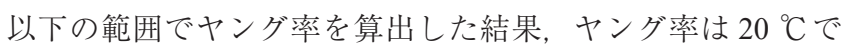
$9.71 \mathrm{GPa}, 100{ }^{\circ} \mathrm{C}$ で $21.0 \mathrm{GPa}$ であり, 加熱により約 $116 \%$ 増 加していることを確認した。 なお，ここで示したヤング率の 值は, 10 本の平均值である. 


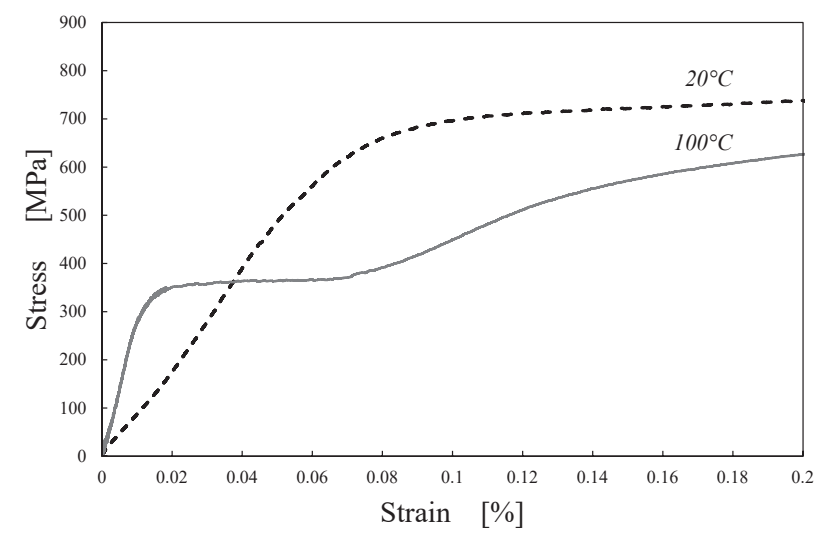

Fig. 3 Stress-Strain curve of the SMA yarn.

\subsection{SMA 糸の糸径}

加熱による曲げ剛性の増加に影響を与えるもう一つのパラ メータとして, 糸径の変化が考えられる. SMA 糸は加熱に より長さ方向に収縮するため, 加熱時は非加熱時に比べ線径 が大きくなっている可能性もある。そこで, デジタルマイク ロスコープ（VHX-6000，株式会社キーエンス製）を使用し て，透過照明による影を撮影し，その画像から糸径を計測し た。測定に使用した画像取得時のレンズ倍率（光学式倍率） は 1500 倍であり, 室温 $20{ }^{\circ} \mathrm{C}$ の環境下において 10 回の計測

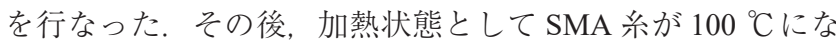
るように通電加熱した状態で，同様の測定を行なった。その 結果，糸径の平均值は非通電時 $\left(20{ }^{\circ} \mathrm{C}\right.$ 状態) で $0.151 \mathrm{~mm}$, 通電時 $\left(100{ }^{\circ} \mathrm{C}\right.$ 状態) で $0.156 \mathrm{~mm}$ であった。この結果から, 使用している SMA 糸は加熱により直径が $3.3 \%$ 増加してい ることを確認した。

\section{$2.3 \mathrm{SMA}$ 平編地の収縮力の算出}

前報 [26]において純曲げ試験機で測定した曲げ剛性值は 非加熱時 $2.7 \times 10^{-7} \mathrm{Nm}^{2}$, 加熱時 $5.7 \times 10^{-7} \mathrm{Nm}^{2}$ であったが, 加 熱時の $M-K$ 曲線に歪がみられるなど信頼性に欠けていた。 今回, Table 1 に示すように各温度状態において具体的に糸の ヤング率と直径の測定を行ない曲げ剛性を算出した結果, 非 加熱時は $2.5 \times 10^{-7} \mathrm{Nm}^{2}$ と約 $7 \%$ 小さい值, 加熱時は $6.1 \times 10^{-7}$ $\mathrm{Nm}^{2}$ と約 $7 \%$ 大きい值となった。この結果, 加熱時の曲げ剛 性の増加率は $144 \%$ と純曲げ試験機で測定した $111 \%$ に比べ $33 \%$ 大きい結果となった。そこで，系の収縮とヤング率と 糸径の変化による曲げ剛性の増加の影響を含めた SMA 平編 地の理論収縮力を算出した。 その結果, Fig. 4 に示すとおり, $4 \%$ の収縮のみで曲げ剛性は変わらないとして式 (1), (2) で

Table 1 Data used to calculate bending rigidity.

\begin{tabular}{|c|c|c|c|}
\hline & $E[\mathrm{GPa}]$ & $d[\mathrm{~mm}]$ & $I\left[\mathrm{~mm}^{4}\right]$ \\
\hline $20^{\circ} \mathrm{C}$ & 9.71 & 0.151 & $2.55 \times 10^{-5}$ \\
\hline $100^{\circ} \mathrm{C}$ & 21.0 & 0.156 & $2.91 \times 10^{-5}$ \\
\hline
\end{tabular}

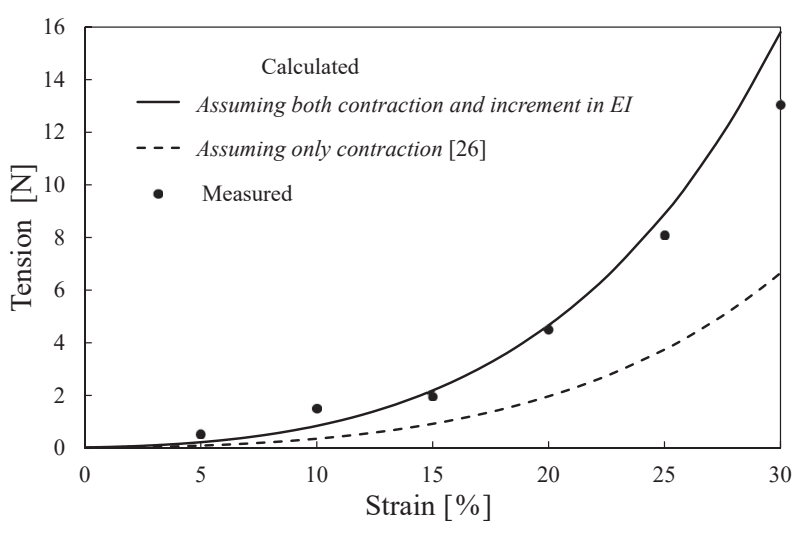

Fig. 4 Calculated and measured tension of the contracted SMA plain knitted fabric at $100^{\circ} \mathrm{C}$.

$P / k_{u}=-0.04$ として扱い, 曲げ剛性は非加熱時の值を用いて計 算した理論值では SMA 平編地の加熱による収縮力実測值と の乘離が大きかったのに対し，糸の曲げ剛性の増加も反映さ せた計算值では $5 \%$ 毎に $30 \%$ まで伸長させた際の張力の実 測值との差が小さくなり，収縮力の計算精度が向上する妥当 な一致をみた。

\section{3. 編目のモデリングについて}

曲げ剛性の変化量を反映させることで SMA 編地の収縮力 をより良い精度で算出することができた。しかし，これ以 上の精度向上には一般的な編地のための式の流用ではなく, SMA 編地に適した式の創出が必要である。 そこで, 本報で は最も基本となる編目のモデリングについて検討することと した。

\section{1 紸のモデリング}

糸のモデリングについては, 若松ら [30] が Fig. 5 のように 提案している。系の長さを $L$ として左端に空間座標系を固定 し, 糸長 $s$ の点 $P(s)$ において糸の中心軸方向に $\zeta$ 軸を一致 させるように物体座標系 $P(s)-\xi \eta \zeta$ を設定することで, 変形 後の物体座標系の向きはオイラー角 $\varphi(s), \theta(s), \psi(s)$ で表 わされる。そのポテンシャルエネルギー $U$ は, $\eta$ 軸方向の曲 げ変形の曲率 $\omega_{\xi}(s), \xi$ 軸方向の曲げ変形の曲率 $\omega_{\eta}(s)$, 曲げ 剛性 $R_{f}$, 中心軸回りのねじれ率 $\omega_{\zeta}(s)$, ねじり剛性 $R_{t}$ を用い て式(3)のように表わすことができる.

$$
U=\frac{R_{f}}{2} \int_{0}^{L}\left(\omega_{\xi}^{2}+\omega_{\eta}^{2}\right) d s+\frac{R_{t}}{2} \int_{0}^{L} \omega_{\zeta}^{2} d s
$$

ここで, モデルを簡略化するために Fig. 6のようにループを二 次元平面内でのみの変形とし，変形後の物体座標系の向きを $\theta(s)$ と表わすと, ループのポテンシャルエネルギーUは式 (4) のように糸の曲げ変形の曲率 $\kappa(s)=d \theta / d s$ のみで表される. 


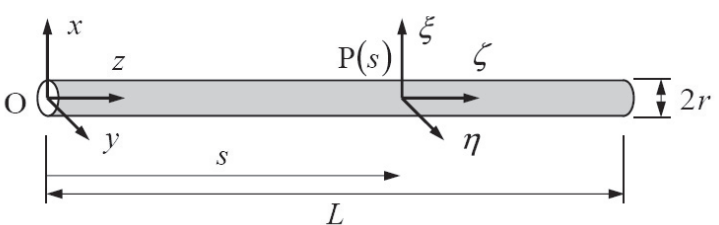

(a)

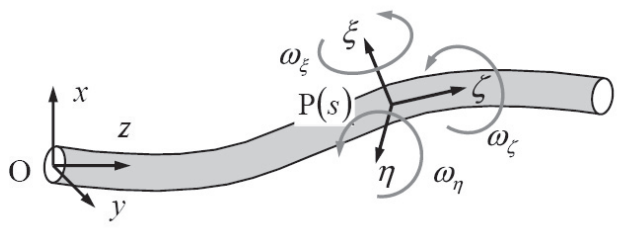

(b)

Fig. 5 3D Modeling of yarn[30]. (a)Initial shape (b)Deformed shape

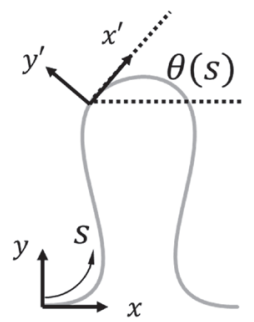

Fig. 6 2D Modeling of yarn.

$$
U=\frac{R_{f}}{2} \int_{0}^{L} \kappa^{2}(s) d s
$$

このポテンシャルエネルギーUが最小になる状態が糸の安定 状態であり, 曲率 $\kappa(s)$ が求まることで糸の状態を定義できる. そして編地が伸長されループが変形した際のポテンシャルエ ネルギーUの増加が収縮力に大きく影響すると考えられる. このことから，収縮力を計算するために糸の状態を定義する にはその曲率が容易に求まることが重要である。

\section{2 クロソイド曲線を用いた編目モデリング}

これまで用いてきた編目は Fig. 1 に示すようにループの頂 点を基準点としてモデリングをしている。しかし，実際には Fig. 7 のように編目は糸が交差する白塗点を代表とするよう な 4 か所で拘束されており, 編地が伸長・収縮するなどの変 形時に一つの編目に力が直接作用する点は編地の端部以外の 大部分において糸が交差するこの 4 点のみであり, Fig. 1 の モデルのようにループの頂点に力がかかることはない．福田 らは糸が交差する 4 点にループの頂点 2 点を加えた 6 点を, カーディナルスプライン曲線を用いて補間する 3 次元モデリ ング手法を提案している [31] が, 編地の変形やそれにともな う収縮力の計算までには言及されていない。そこでループの 変形や伸長時の張力の計算を容易に可能とするために, 力が 直接作用する 4 点を通る補間曲線として曲率の算出が容易な

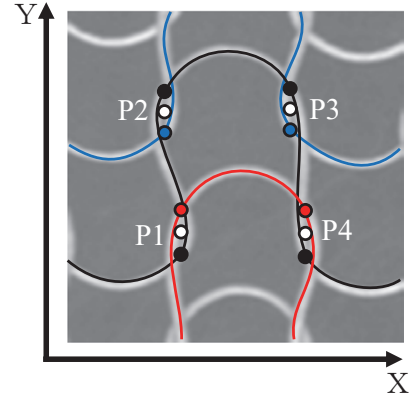

Fig. 7 Force acting points on a stitch in photograph.

クロソイド曲線を用いることで，ループをモデリングするこ とを提案する. クロソイド曲線は, 曲線の長さに比例して曲 率が変化する曲線であり, 与えられた点列間をなめらかに接 続し, 曲率が連続的に変化する曲線である。一般に, 自由曲 線補間の問題では，連続性がよく曲率が小さい解が得られる [27-29]. 今回は一番簡単な 2 次元平面上に拈いてモデリン グを行なった。ただし，ループをモデリングする際に基準と なる 4 点を P1 P4 とすると, 糸の太さを無視した場合 Fig. 7 に示す白塗点となるが，実際には糸に太さがあるため接触位 置は点とはならず,（後述の Fig. 10 などの）画像でも確認で きるように一定の範囲に分布した状態となる。そこで，糸の 太さを考慮して P2, P3 の 2 点は Y プラス方向に, P1, P4の 2 点は Y マイナス方向に移動させた黒塗点をモデリングの基 準点とした。同様に，青ループにおいてはP2，P3の 2 点は Y マイナス方向に移動した青塗点，赤ループにおいては $\mathrm{P} 1$, P4の 2 点は Y プラス方向に移動させた赤塗点をそれぞれの ループの基準点とした。 以下にその方法と，モデリングした 結果を示す.

まず，モデリングのための基準点となる 4 点の座標を $\mathrm{P} 1$ $(a, 0), \mathrm{P} 2(a, b), \mathrm{P} 3(2 a, b), \mathrm{P} 4(2 a, 0)$ として基本的な編目のモ デリングを行なう。この 4 点とつながる前後の点は $\mathrm{P} 0(0,0)$ と P5 $(3 a, 0)$ とし, 各点での接線方向は接続点とその前後の 点を直線で結んだ方向べクトル（弦ベクトル）が転向した角 度を二等分する弦べクトル転向角二分法を用い，各点の接線 方向は Fig. 8 に示すとおり $\pm 45^{\circ}$ とした。これは，無負荷時 はループが安定した形状に落ち着いていることから, クロソ

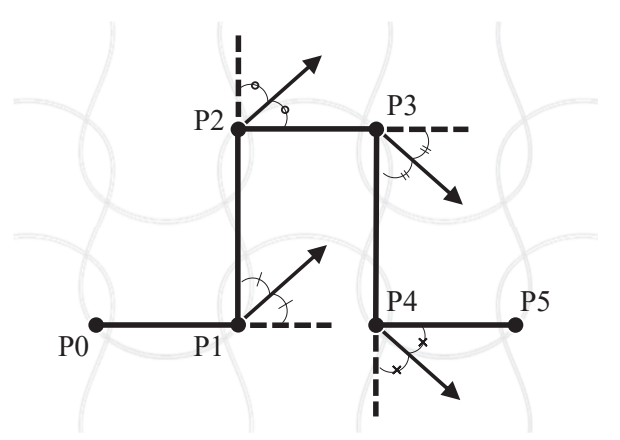

Fig. 8 Tangential direction at each point via bisection method of chord vector deflection angle. 


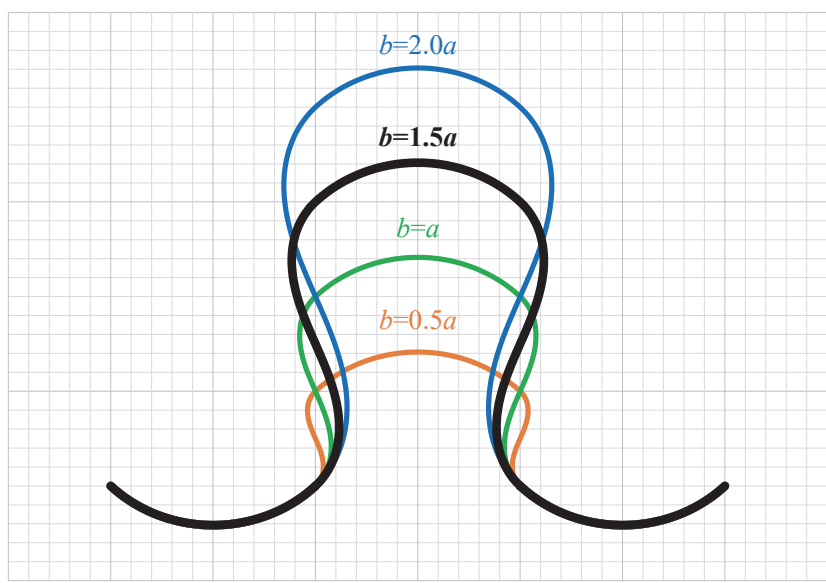

Fig. 9 Model of clothoid curve for a stitch.

イド曲線の接続点となる交差点に打いても接線方向が一致す るとしたことによる。な㧍，Fig. 8 に打ける点線は接続点ま での弦ベクトルの方向をわかりやすくするために，接続点に て延長したものである。これらの条件のもとで $b$ を $0.5 a$ か ら $2 a$ まで 0.5 刻みでモデリングした結果, Fig. 9 のように全 てなめらかで違和感のない編目をモデリングできることを 確認した。な㧍，Fig.9のクロソイド曲線の 1 周期の全長は $3.33 a+2.13 b$ であり, 1 ループの糸長を P0 と P1 を結ぶ曲線の 中点から P4 と P5 を結ぶ曲線の中点までとすると，その長さ は $2.22 a+2.13 b$ となった。

福田ら［31］は作製した編地サンプルのループ長の実測值 とモデリングしたループ長が近似する值となっていること でその妥当性を評価した。そこで，同様に試作した SMA 編 地の画像から力が基準点となる 4 点を測定し, $a=1.39 \mathrm{~mm}$, $b=2.03 \mathrm{~mm}$ としてモデリングした結果，ループ長は $7.47 \mathrm{~mm}$ となった。編地をほどいて 1 コース分の糸長を測定しウェー ル数で割ることで算出した編目一つ当たりの糸長 (ループ長) は $7.93 \mathrm{~mm}$ であり，実測值を $100 \%$ とした場合に比べ $5.8 \%$ 小さい $94.2 \%$ であった. 糸の太さや 3 次元方向の生地の厚 みを考慮すると計算值は大きくなることから，本モデリング 手法は妥当であると判断した。

\section{3 編目の変形モデリング}

編目の変形については, 編地を二軸伸長させた場合の挙動 について川端らにより理論解析されている [32]. その挙動 は，伸長率が小さいときは Fig. 10(a)のように糸が曲がった 状態でその交差点がずれていくこと，その後，一定以上の伸 長率になると糸のずれが止まり, Fig. 10(b) のように糸の曲 がりが伸びて真っ直ぐになっていき，Fig. 10(c) に示すよう に糸が真っ直ぐになった後は糸が伸長される状態へと移行し ていくことが示されている，また，この糸の曲がりが伸びて 真っ直ぐになるまでは糸の伸びの影響がほとんどないとされ ている. 以上のことから, 今回提案したモデリング手法は伸 長率が小さい状態，すなわち交点がずれていく範囲につい ては，SMA糸に限らず編地全般に適用できる。そこで, 編 地が伸長された時の編目を試作したSMA 編地の比である $b=1.46 a$ として, 以下のようにモデリングした。編地がウェー ル方向に伸長されたとすると, $\mathrm{P} 1(a, 0), \mathrm{P} 2(a, 1.46 a)$ 間と $\mathrm{P} 3$ $(2 a, 1.46 a), \mathrm{P} 4(2 a, 0)$ 間の距離が大きくなる。一軸引張の場合, コース方向に収縮するため次のように計算した，仮に編地の ウェール方向伸長率を $10 \%$ とし，P1 $(a, 0)$ を基準点（動かさ ない点) とすると, $\mathrm{P} 2(a, 1.46 a)$ は $10 \% \mathrm{Y}$ 軸方向に伸びるため, その座標は P'2 $(a, 1.61 a)$ となる。 P3, P4 は同じ X座標をとり, $\mathrm{Y}$ 座標は, P3 はP2 と P4 は P1 と同じ値となることから, P’3 $(x, 1.61 a), \mathrm{P}{ }^{\prime} 4(x, 0)$ とできる。金属瀻維（SMA 糸を含む）に 限らず $10 \%$ 伸長では編目の交差点がずれていく領域であり 糸自体の伸びは影響しないと考えられることから, 系長は変 化しない，そこでループ長を変形前の值と同じ $5.33 a$ となる ように調整した結果が Fig. 11 である。この時の接線角度は 変わらず $\pm 45^{\circ}$ であり， P'2 P'3 は $0.86 a$ となった。変形前の P1P2（P3P4）間 $1.55 a$ 及び, P2P3 間の糸長 $1.11 a$ が変形後の P1P'2（P'3P'4）間は 1.71a，P'2P'3 間の糸長は $0.96 a$ となり 交差点のずれが表現できていることを確認した。そして伸長 時の張力発生メカニズムとしてこれまでにループ頂点の曲げ 変形が大きく影響していると考えられてきた $[25,32]$ ことか ら, P'2P'3 間の曲率に注目すると, 変形前の P2P3 間の曲率 は 1.41/aであったが変形後は 1.64/a と増加して扔り, P'2P'3 間のポテンシャルエネルギーUが増加する結果となることを

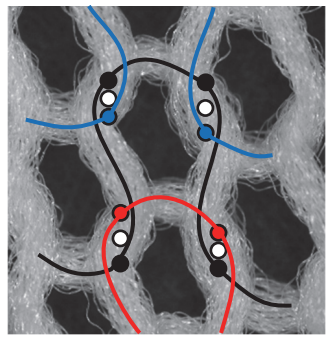

(a)

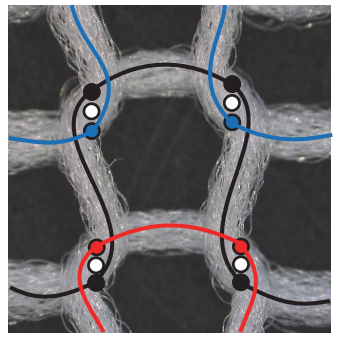

(b)

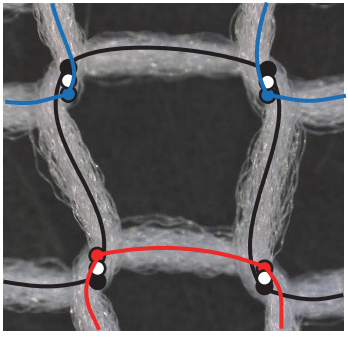

(c)

Fig. 10 Deformation behavior of stitches.

(a)The range where intersection points of yarns shift

(b)The range where the yarns deform straight

(c)The range where the yarns stretch 


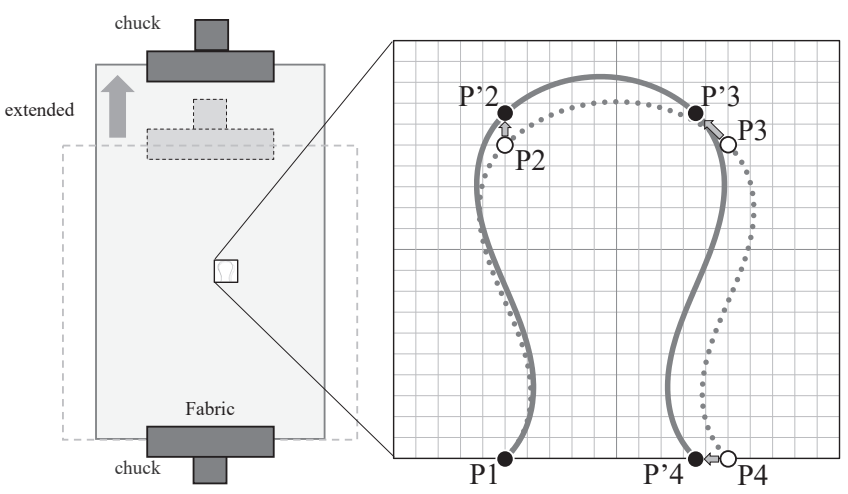

Fig. 11 Clothoid curve of the stitch model stretched for wale direction.

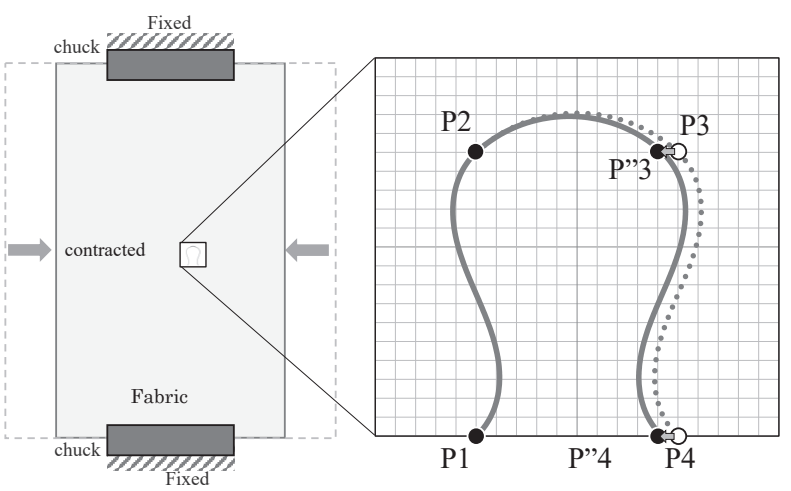

Fig. 12 Clothoid curve of the stitch model for yarn contraction.

確認した。な抄，Fig. 11 に打いては，P'0P1 間，P'4P'5 間の 曲線は P’2P'3 間の曲線を X 軸対称に反転したものとなるこ とから省略した。

次に，加熱により SMA 糸が収縮する場合について検討す る. SMA 平編地のウェール方向伸長時の発生力測定に扔い ては, SMA 糸が収縮するとき編地のウェール方向両端は固 定されている，そのためP1P2 間と P3P4 間の距離は変化しな い. 一方で, 糸長は $4 \%$ 短くなるためコース方向に収縮する. 一軸伸長の場合と同様に P1 を基準点とすると, P2 も移動し ない点となる。そして，P3，P4 は同じX座標をとり，それ ぞれ P”3 $(x, b), \mathrm{P} " 4(x, 0)$ となる。ここで試作した SMA 編地 の比である $b=1.46 a$ として，10\%伸長時にループ長が加熱に より $5.33 a$ から $4 \%$ 短い $5.11 a$ になったとしてモデリングし た結果を Fig. 12 に示す。この結果, P2 P”3 は $0.86 a$ から $0.83 a$ とコース方向に $3.0 \%$ 収縮し, 曲率は $1.64 / a$ から $1.94 / a$ と増 加しており P2 P”3 間のポテンシャルエネルギーUが増加す る結果となることを確認した。

\section{4. 結 言}

SMA 平編地の発生収縮力算出の精度向上を目的に, 非加 熱時と加熱時のSMA 糸のヤング率と糸径を測定した。この 測定值を用いて算出した曲げ剛性值を用いることで，SMA 平編地の加熱による発生収縮力の算出精度を向上させること
ができた。また，さらなる精度向上を目的に，SMA 編地に より適した編目モデルとして, クロソイド曲線を補間曲線 とする編目のモデリングを行なった，そして，このモデル がSMA 糸の収縮による曲率変化によるポテンシャルエネル ギーの増加を表現でき, 糸の収縮により編地が発生する収縮 力の解析に適用可能なことを示した。

今回提案したクロソイド曲線による補間モデリングは, 編 目の変形時の各接触点間の糸長を容易に算出できることか ら，スマートテキスタイルに执いて用いられる導電系を編み 込んだ編地センサなどの変形時の挙動と抵抗值変化など，セ ンサ機能の解析にも応用可能と考えている。特に, SMA 編 地に扔いてはその伸び量をセンシングする自己センシング機 能の搭載を検討し，その挙動を制御できるように取り組んで いく予定である.

\section{謝 辞}

本研究の一部は JSPS 科研費 $20 K 04374$ の助成を受けたも のです。

\section{References}

[1] Murakami T, Masuda A, Yoshida Y, Iemoto Y, Uematsu H, Tanoue S (2016) Journal of Textile Engineering, 62, 51-56 (in Japanese). https://doi.org/10.4188/jte.62.51

[2] Murakami T, Masuda A, Sasaji T, Iemoto Y, Uematsu H, Tanoue S (2016) Journal of Textile Engineering, 62, 117-122 (in Japanese). https://doi.org/10.4188/jte.62.117

[3] Murakami T, Masuda A, Kondo K, Sasaji T, Iemoto Y, Uematsu H, Tanoue S (2016) Journal of Textile Engineering, 62, 181-185 (in Japanese). https://doi.org/10.4188/jte.56.181

[4] Murakami T, Masuda A, Hirakue M, Iemoto Y, Uematsu H, Tanoue S (2016) Journal of Fiber Science and Technology, 72, 120-125 (in Japanese). https://doi.org/10.2115/ fiberst.2016-0018

[5] Fujioka J, Kuroda N (2014) Sen'i Kikai Gakkaishi (Journal of the Textile Machinery Society of Japan), 67, 115-119 (in Japanese)

[6] Fujioka J, Yoshida Y, Ise T, Seki H (2018) Journal of Textile Engineering, 64, 19-27 (in Japanese). https://doi.org/10.4188/ jte. 64.19

[7] Namikawa S, Enokibori Y, Mase K (2016) Interaction 2016 Ronbunshu, Information Processing Society of Japan, 396401 (in Japanese)

[8] Sakaguchi A, Kato M, Ishizawa H, Kimura H, Koyama S (2016) Journal of Textile Engineering, 62, 129-134 (in Japanese). https://doi.org/10.4188/jte.62.129

[9] Shimakami Y, Horiba T, Tanaka T, Miyamoto K, Enokibori Y, Mase K, Kawabe T, Shimizu T, Yanagisawa S, Mizuno H, Suzuki A (2016) Technical Report of Aichi Center for Industry and Science Technology 2016, 22-125

[10] Koyama S, Sakaguchi A, Ishizawa H, Yasue K, Oshiro H, 
Kimura H (2017) Journal of Fiber Science and Technology, 73, 300-308. https://doi.org/10.2115/fiberst.2017-0046

[11] Koyama S, Ishizawa H, Hosoya S, Kawamura T, Chino S (2017) Journal of Fiber Science and Technology, 73, 276283. https://doi.org/10.2115/fiberst.2017-0042

[12] Suganuma K (2017) "Advances in Healthcare Wearable Devices”, CMC Publishing, Tokyo (in Japanese)

[13] Kasai N, Ogasawara T, Nakashima H, Tsukada S (2017) IEICE Communications Society Magazine, 41, 17-23 (in Japanese). https://doi.org/10.1587/bplus.11.17

[14] Tada Y, Inoue M, Tokumaru T (2013) Journal of Textile Engineering, 59, 141-148. https://doi.org/10.4188/jte.59.141

[15] Suzumori K (2015) Journal of the Robotics Society of Japan, 33, 656-659 (in Japanese). https://doi.org/10.7210/jrsj.33.656

[16] Asaka K (2016) Synthesiology, 9, 117-123 (in Japanese). https://doi.org/10.5571/synth.9.3_117

[17] Haines CS, Lima MD, Li N, Spinks GM, Foroughi J, Madden JDW, Kim SH, Fang S, Jung de Andrade M, Göktepe F, Göktepe Ö, Mirvakili SM, Naficy S, Lepró X, Oh J, Kozlov ME, Kim SJ, Xu X, Swedlove BJ, Wallace GG, Baughman RH (2014) Science, 343, 868-872. http://doi.org/10.1126/ science. 1246906

[18] Maziz A, Concas A, Khaldi A, Stalhand J, Persson N, Jager EWH (2017) Science Advances, 3, e1600327. http://doi. org/10.1126/sciadv. 1600327

[19] Dono S, Saito A, Kuwata T (2003) Matsushita Electric Works technical report, Aug, 59-63 (in Japanese)

[20] Saito T, Ji Q, Goto K (2005) Transactions of the Japan Society of Mechanical Engineers Series C, 71, 2312-2327 (in Japanese). https://doi.org/10.1299/kikaic.71.2321

[21] Hatamura M (2016) "A study on development of new actuators using a Ti-Ni shape memory alloy (SMA) and Febased SMA", Yokohama National University, Japan, Ph. D. thesis (in Japanese)

[22] Abel J, Luntz J, Brei D (2012) Smart Materials, Adaptive Structures and Intelligent Systems, 21, 085011. https://doi. org/10.1115/SMASIS2009-1426

[23] Abel J, Luntz J, Brei D (2013) Smart Materials and
Structures, 22, 125001. https://doi.org/10.1088/0964$1726 / 22 / 12 / 125001$

[24] Nakashima A, Higuchi Y, Wakako L, Kinari T (2018) Journal of Textile Engineering, 64, 133-139 (in Japanese). https:// doi.org/10.4188/jte.64.133

[25] Shimizu Y, Ikemura S, Tabata M, Uno M (1966) Journal of the Textile Machinery Society of Japan (predecessor journal of Journal of Textile Engineering), 19, T301-T308 (in Japanese). https://doi.org/10.4188/transjtmsj1965b.19.T301

[26] Nakashima A, Higuchi Y, Wakako L, Kinari T (2019) Journal of Textile Engineering, 65, 47-53 (in Japanese). https://doi. org/10.4188/jte.65.47

[27] Makino H (1994) Journal of the Japan Society for Precision Engineering, 60, 80-85 (in Japanese). https://doi.org/10.2493/ jjspe. 60.80

[28] Qiu S, Suda H, Makino H (1994) Journal of the Japan Society for Precision Engineering, 60, 1596-1600 (in Japanese). https://doi.org/10.2493/jjspe.60.1596

[29] Lan A, Tamai H, Makino H (2010) Journal of the Japan Society for Precision Engineering, 76, 1194-1199 (in Japanese). https://doi.org/10.2493/jjspe.76.1194

[30] Wakamatsu H, Inoue M, Kurashiki T, Morinaga E, Arai E, Takeuchi S (2014) Journal of Textile Engineering, 60, 41-50 (in Japanese). https://doi.org/10.4188/jte.60.41

[31] Fukuta Y, Ohta K, Kinari T (2011) Journal of Textile Engineering, 57, 37-44 (in Japanese). https://doi.org/10.4188/ jte. 57.37

[32] Kawabata S, Niwa M, Nanashima Y, Kawai H (1970) Journal of the Textile Machinery Society of Japan (predecessor journal of Journal of Textile Engineering), 23, T95-T108 (in Japanese). https://doi.org/10.4188/transjtmsj1965b.23.T95

\section{文献（日本語表記）}

[7］並川真也, 榎堀優, 間瀬健二 (2016) インタラクション 2016 論文集（情報処理学会），396-401

[12］菅沼克昭監修 (2017) “ヘルスケア・ウェアラブルデバ イスの開発”, シーエムシー出版 